\title{
A phase II study of single-agent gefitinib as first-line therapy in patients with stage IV non-small-cell lung cancer
}

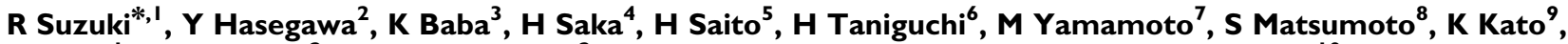 \\ T Oishi ${ }^{1}, K_{\text {Imaizumi }}{ }^{2}$ and $K_{\text {Shimokata }}{ }^{2}$, on behalf of the Central Japan Lung Study Group ${ }^{10}$ \\ 'Toyohashi Municipal Hospital, 50 Hachiken-nishi, Aotake, Toyohashi, Aichi 44 I-8570, Japan; ${ }^{2}$ Nagoya University Graduate School of Medicine, 65 \\ Tsuruma, Showa-ku, Nagoya 466-8550, Japan; ${ }^{3}$ Aichi Medical University, 21 Karimata, lyazako, Nagakute, Aichi 480-1 195, Japan; ${ }^{4}$ Nagoya Medical \\ Center, 4-I - I, Sannomaru, Naka-ku, Nagoya 460-000 I, Japan; ${ }^{5}$ Aichi Cancer Center, 18 Kake-machi, Kuriyado, Okazaki, Aichi 444-00 II, Japan; ${ }^{6}$ Tosei \\ General Hospital, 160 Nishioiwake, Seto, Aichi 489-8642, Japan; ${ }^{7}$ Nagoya Ekisaikai Hospital, 4-66, Syonen-cho, Nakagawa-ku, Nagoya 454-8502, \\ Japan; ${ }^{8}$ Komaki Municipal Hospital, I-20, Tsunebushin, Komaki, Aichi 485-8520, Japan; ${ }^{9}$ Handa Municipal Hospital, 2-29, Toyo-cho, Handa, Aichi 475- \\ 8599, Japan
}

The aim of this study was to evaluate the efficacy and tolerability of gefitinib ('IRESSA') in Japanese patients with previously untreated stage IV non-small-cell lung cancer (NSCLC). This was a multi-institutional phase II study. Thirty-four patients with previously untreated stage IV NSCLC were enrolled between May 2003 and September 2004. Gefitinib was administered orally 250 mg once a day and was continued until there was either disease progression or severe toxicity. Objective tumour response rate was $26.5 \%$ (95\% confidence interval, I I.7-41.3\%). Adverse events were generally mild (National Cancer Institute-Common Toxicity Criteria grade I or 2) and consisted mainly of skin rash, fatigue and liver dysfunction. No pulmonary toxicity was observed. The global health status revealed that there was no change in quality of life during the study. This study found that single-agent gefitinib is active and well tolerated in chemonaive Japanese patients with advanced NSCLC.

British Journal of Cancer (2006) 94, I599- |603. doi:I0.I038/sj.bjc.6603 I 59 www.bjcancer.com

Published online 2 May 2006

(c) 2006 Cancer Research UK

Keywords: gefitinib; IRESSA; non-small-cell lung cancer

Gefitinib is an epidermal growth factor receptor (EGFR) tyrosine kinase (TK) inhibitor that blocks signal pathways involved in proliferation and survival of cancer cells (Wakeling et al, 1996). A phase I clinical trial showed that gefitinib is well tolerated and active in solid, malignant tumours (Ranson et al, 2002). Two large randomised phase II studies in patients with non-small-cell lung cancer (NSCLC) who had progressive disease (PD) following platinum-based chemotherapy, IRESSA Dose Evaluation in Advanced Lung Cancer (IDEAL 1) and 2 demonstrated response rates of 12-18\%. (Fukuoka et al, 2003; Kris et al, 2003). A higher response rate of $28 \%$ was observed in Japanese patients in IDEAL 1 , which is comparable to the response rate of $19 \%$ shown in the ECOG randomised study of four platinum-based chemotherapy regimens (Schiller et al, 2002). Gefitinib showed encouraging response rate $(23 \%, 5$ out of 22$)$ and survival benefit (median survival 12.6 months) as a first-line therapy in NSCLC in the compassionate use (Argiris and Mittal, 2004) and a response rate of $27 \%$ (10 out of 37) in Japanese chemonaive patients with advanced NSCLC (Niho et al, 2004). The adverse effects of gefitinib were generally mild such as skin eruption, diarrhoea and nausea. These data suggest that further clinical evaluation of gefitinib in

\footnotetext{
*Correspondence: Dr R Suzuki; E-mail: rsuzuki-alg@umin.ac.jp

${ }^{10}$ Central Japan Lung Study Group, Department of Respiratory Medicine, Nagoya University Hospital: 65 Tsuruma, Showa-ku, Nagoya 466-8550, Japan

Received 2 February 2006; revised 6 April 2006; accepted 6 April 2006; published online 2 May 2006
}

Japanese chemonaive patients is warranted. Therefore, we evaluated the efficacy and tolerability of gefitinib as a first-line therapy in a Japanese patient population. When disease progression was observed, the standard platinum-based doublet chemotherapy was considered to use as salvage.

\section{MATERIALS AND METHODS}

\section{Patients}

This study began in May 2003 and ended in September 2004. Patients inclusion criteria were as follows: (1) Stage IV NSCLC without previous chemotherapy or radiotherapy; (2) patients who had measurable lesions; (3) patients whose ages were $20 \leqslant$ age $<75$; (4) patients whose Eastern Cooperative Oncology Group-Performance Status (ECOG-PS) were 0 or 1 ; (5) patients who had adequate organ function; partial pressure of oxygen in arterial blood $\left(\mathrm{PaO}_{2}\right) \geqslant 70$ Torr, adequate bone marrow (absolute neutrophil count $\geqslant 1500 \mathrm{~mm}^{-3}$, platelets $\geqslant 100000 \mathrm{~mm}^{-3}$, haemoglobin $\geqslant 10 \mathrm{~g} \mathrm{dl}^{-1}$ ), renal function (serum creatinine $\leqslant 1.25 \times$ upper normal limit) and hepatic function (serum glutamic-oxaloacetic transaminase and serum glutamic pyruvic transaminase $\leqslant 1.25 \times$ upper normal limit). All patients with interstitial pneumonia were strictly excluded by chest computed tomography (CT).

All patients gave written informed consent before enrollment. This protocol was approved by the Institutional Review Boards of the participating centres. 


\section{Treatment}

Patients received gefitinib $250 \mathrm{mg}$ orally, once a day. Study treatment was continued until disease progression or severe toxicity. In these cases, patients received carboplatin (CBDCA) and paclitaxel (TXL) chemotherapy as second-line therapy. Patients received TXL $200 \mathrm{mg} \mathrm{m}^{-2}$ as a 1-h intravenous infusion, followed by CBDCA area under the curve (AUC) 6.0 (Calvert's setting) as a 1 -h infusion on day 1 . Courses of treatment were repeated every 3 or 4 weeks depending on the recovery of toxicity.

Tumour response was assessed as complete response (CR), partial response (PR), stable disease $\geqq 12$ weeks (SD), or PD in accordance with the standard Response Evaluation Criteria In Solid Tumours (RECIST). Toxicity was evaluated using National Cancer Institute-Common Toxicity Criteria (NCI-CTC) (version 2). Quality of life (QOL) was evaluated before the start of therapy and at 4 and 12 weeks, using the European Organisation for Research and Treatment of Cancer Care Quality of Life Questionnaire (EORTC-QLQ-C30) and lung-cancer-specific module (LC13) (Aaronson et al, 1993).

\section{Statistical considerations}

The primary end point was response rate. The secondary end points were toxicity, survival from the date of enrolment and QOL. According to Simon's minimax two-stage phase II study design, the treatment programme was designed for a minimal response rate of $15 \%$ and to provide a significance level of 0.10 with a statistical power of $80 \%$ in assessing the activity of the regimen according to a $35 \%$ response rate. The upper limit for first-stage drug rejection was two responses in 17 evaluable patients. The upper limit for second-stage drug rejection was nine responses in 32 evaluable patients. We chose a sample number of 34 , to allow for two dropouts. Tumour responses in subsets were compared using Fisher's exact test. Quality-of-life analyses were performed using Wilcoxon's signed-rank test. All $P$-values were considered significant if $\leqslant 0.05$.

\section{RESULTS}

\section{Patient characteristics and treatment administration}

Thirty-four patients were enrolled and all of them were eligible. Patient characteristics are shown in Table 1. Of the 34 patients, 21 were men and 13 were women. Median age was 64 years (range: 43-73). The ECOG-PS was 0 in 16 patients and 1 in 18 patients. The predominant histology was adenocarcinoma (25 patients). Twenty-three patients had smoking history (including current smoker or ex-smoker). Of the 34 patients, 33 patients discontinued gefitinib treatment. The reasons for discontinuing treatment were progression of disease $(n=30)$, toxicities (skin; $n=1$, liver; $n=1$ ) and patient request $(n=1)$. The median treatment period was 2.4 months (range: 1-23 months). Only one patient is still receiving treatment with gefitinib.

Table I Patient characteristics

\begin{tabular}{llc}
\hline Sex & Male/female & $\mathbf{2}$ I/13 \\
\hline Age & Median (range) & $64(43-73)$ \\
ECOG-PS & O/I & $16 / 18$ \\
Histology & Ad/Sq/Other & $25 / 5 / 4$ \\
Smoking history & Yes/never & $23 / 11$ \\
Clinical stage & Stage IV & 34 \\
\hline
\end{tabular}

Ad = adenocarcinoma; $\mathrm{Sq}=$ squamous-cell carcinoma; ECOG-PS = Eastern Cooperative Oncology Group Performance Status.

\section{Response}

Nine patients (26.5\%) achieved PR, and eight patients (23.5\%) had SD as their best response. The objective response rate was $26.5 \%$ (95\% CI, 11.7-41.3\%). Subset analysis is shown in Table 2. Seven out of the 13 female patients achieved PR. There was a statistically significant difference between men and women. However, other factors such as pathology, smoking history and ECOG-PS demonstrated no significant difference. Median duration of response was 8.8 months (range 2.1-22.0 months). Median follow-up was 15.8 months (range 2.9-33.8 months).

\section{Overall survival}

Median survival time was 14.1 months. The 1-year survival rate was $58.2 \%$. Twenty-one patients died during the study period, and 13 patients are still alive. The Kaplan-Meier survival curve is shown in Figure 1.

\section{Toxicities}

Thirty-three patients were evaluated for toxicity. One patient demonstrated liver dysfunction from disease progression within 1 week of enrolling and was not evaluated for toxicity assessment. Generally, toxicities were mild. The most common toxicities were skin rash, general fatigue and liver dysfunction (Table 3). Most were grade 1 or 2 in severity and four patients $(11.8 \%)$ experienced grade 3 toxicities (one skin rash, one general fatigue and four liver dysfunction). There was no pulmonary toxicity during the treatment.

\section{Quality of life}

The global health status revealed no significant differences between QOL before gefitinib therapy and 4 or 12 weeks after commencing therapy, compared to baseline. Quality of life-30 scores were $4.7 \pm 1.7$ before therapy, $4.9 \pm 1.3$ after 4 weeks and $4.9 \pm 1.1$ after 12 weeks (Table 4 ). For the other scales, at 12 weeks, improvement of insomnia and constipation, worsening of appetite loss, diarrhoea, financial difficulties and alopecia were observed (Tables 4 and 5).

Table 2 Subset analysis (response rate)

\begin{tabular}{llll}
\hline \multicolumn{1}{c}{ Patient characteristics } & \multicolumn{1}{c}{ Response rate } & P-value \\
\hline Sex & Male vs female & $2 / 21(9.5 \%)$ vs $7 / 13(53.8 \%)$ & 0.0057 \\
Pathology & Ad vs Sq+other & $7 / 25(28 \%)$ vs $2 / 9(22.2 \%)$ & 0.7432 \\
Smoking & Current+ex-smoker vs $4 / 23(17.4 \%)$ vs $5 / 11(45.5 \%)$ & 0.1009 \\
ECOG-PS & never smoker & & \\
& 0 vs I & $5 / 16(31.3 \%)$ vs 4/18 (22.2\%) & 0.5633 \\
\hline
\end{tabular}

$\mathrm{Ad}=$ adenocarcinoma; $\mathrm{Sq}=$ squamous-cell carcinoma; ECOG-PS = Eastern Cooperative Oncology Group Performance Status.

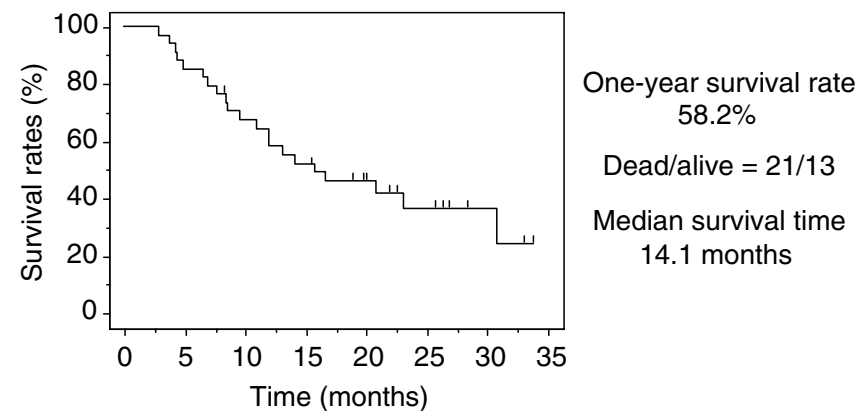

Figure I Kaplan-Meier survival curve. 
Table 3 Toxicities (NCl-CTC version 2.0)

\begin{tabular}{lcccc}
\hline & \multicolumn{4}{c}{ No. of patients } \\
\cline { 2 - 5 } Grade & $\mathbf{I}$ & $\mathbf{2}$ & $\mathbf{3}$ & Total \\
\hline Skin rash & 14 & 5 & 1 & 20 \\
General fatigue & 6 & 3 & 1 & 10 \\
Liver dysfunction & 2 & 4 & 4 & 10 \\
Diarrhoea & 6 & 0 & 0 & 6 \\
Nausea & 4 & 2 & 0 & 6 \\
Anaemia & 0 & 1 & 0 & 1 \\
\hline
\end{tabular}

$\mathrm{NCl}-\mathrm{CTC}=$ National Cancer Institute-Common Toxicity Criteria. There were no pulmonary toxicities.

Table 4 Evaluation of the quality of life of patients using the QLQ-C30 questionnaire

\begin{tabular}{|c|c|c|c|}
\hline & $\begin{array}{l}\text { Before therapy } \\
\qquad n=34\end{array}$ & $\begin{array}{c}\text { After } 4 \text { weeks } \\
n=32\end{array}$ & $\begin{array}{c}\text { After } 12 \text { weeks } \\
n=20\end{array}$ \\
\hline $\begin{array}{l}\text { Global health } \\
\text { status/QOL } \\
\text { Functional scales }\end{array}$ & $4.7 \pm 1.7$ & $4.9 \pm 1.3$ & $4.9 \pm 1.1$ \\
\hline $\begin{array}{l}\text { Physical } \\
\text { functioning }\end{array}$ & $94.0 \pm 7.2$ & $94.6 \pm 7.0$ & $93.3 \pm 6.4$ \\
\hline $\begin{array}{l}\text { Role functioning } \\
\text { Emotional }\end{array}$ & $\begin{array}{l}94.6 \pm 13.2 \\
82.8 \pm 19.7\end{array}$ & $\begin{array}{l}96.2 \pm 7.1 \\
86.6 \pm 13.6\end{array}$ & $\begin{array}{l}93.1 \pm 8.6 \\
86.8 \pm 13.5\end{array}$ \\
\hline functioning & & & \\
\hline $\begin{array}{l}\text { Cognitive } \\
\text { functioning }\end{array}$ & $85.5 \pm 15.4$ & $86.6 \pm 14.5$ & $87.5 \pm 14.4$ \\
\hline $\begin{array}{l}\text { Social functioning } \\
\text { Role functioning }\end{array}$ & $\begin{array}{l}73.7 \pm 26.8 \\
94.6 \pm 13.2\end{array}$ & $\begin{array}{l}79.6 \pm 21.4 \\
96.2 \pm 7.1\end{array}$ & $\begin{array}{l}81.9 \pm 23.0 \\
93.1 \pm 8.6\end{array}$ \\
\hline Symptom scales/item & & & \\
\hline $\begin{array}{l}\text { Fatigue } \\
\text { Nausea and } \\
\text { vomiting }\end{array}$ & $\begin{array}{c}19.4 \pm 17.0 \\
0.5 \pm 3.0\end{array}$ & $\begin{array}{c}23.7 \pm 21.0 \\
1.6 \pm 5.0\end{array}$ & $\begin{array}{c}19.4 \pm 14.3 \\
2.8 \pm 6.5\end{array}$ \\
\hline $\begin{array}{l}\text { Pain } \\
\text { Dyspnoea } \\
\text { Insomnia } \\
\text { Appetitie loss } \\
\text { Constipation } \\
\text { Diarrhoea } \\
\text { Financial } \\
\text { difficulties }\end{array}$ & $\begin{array}{c}18.3 \pm 17.4 \\
15.1 \pm 18.9 \\
30.1 \pm 30.3 * \\
9.7 \pm 15.4 \\
14.0 \pm 18.8 \\
5.4 \pm 12.5 \\
21.5 \pm 31.7\end{array}$ & $\begin{array}{l}14.5 \pm 13.4 \\
19.4 \pm 24.0 \\
14.0 \pm 18.8 * \\
18.3 \pm 24.0 * \\
15.1 \pm 22.5 \\
12.9 \pm 18.6 \\
21.5 \pm 28.0\end{array}$ & $\begin{array}{c}15.3 \pm 16.6 \\
13.9 \pm 17.2 \\
11.1 \pm 16.4 * \\
22.2 \pm 29.6 * \\
0 * \\
25.0 \pm 32.2 * \\
30.6 \pm 38.8 *\end{array}$ \\
\hline
\end{tabular}

QLQ-C30 = Quality of Life Questionnaire; $Q O L=$ quality of life. $* P<0.05$ compared with before therapy.

Table 5 QOL evaluation ( $\mathrm{LCI})$

\begin{tabular}{lccc}
\hline & $\begin{array}{c}\text { Before therapy } \\
\mathbf{n}=\mathbf{3 4}\end{array}$ & $\begin{array}{c}\text { After } \mathbf{4} \\
\text { weeks } \mathbf{n}=\mathbf{3 2}\end{array}$ & $\begin{array}{c}\text { After } \mathbf{~ 2 ~} \\
\text { weeks } \mathbf{n}=\mathbf{2 0}\end{array}$ \\
\hline Symptom scales/items & & & \\
Dyspnoea & $12.5 \pm 17.1$ & $14.0 \pm 17.7$ & $11.1 \pm 16.4$ \\
Coughing & $32.3 \pm 15.8$ & $24.7 \pm 21.0$ & $22.2 \pm 16.4$ \\
Haemoptysis & $4.2 \pm 11.2$ & $8.6 \pm 17.1$ & $8.3 \pm 15.1$ \\
Sore mouth & $6.3 \pm 9.9$ & $9.7 \pm 17.6$ & $5.6 \pm 13.0$ \\
Dysphagia & $3.1 \pm 9.9$ & $6.5 \pm 15.9$ & $11.1 \pm 16.4$ \\
Peripheral neuropathy & $15.6 \pm 17.2$ & $14.0 \pm 18.8$ & $13.9 \pm 17.2$ \\
Alopecia & $3.1 \pm 13.0$ & $7.5 \pm 18.7$ & $16.7 \pm 17.4 *$ \\
Chest pain & $10.4 \pm 15.7$ & $7.5 \pm 14.2$ & $13.9 \pm 17.2$ \\
Arm or shoulder pain & $7.3 \pm 18.4$ & $10.8 \pm 18.0$ & $19.4 \pm 33.2$ \\
Pain in other regions & $26.9 \pm 27.8$ & $18.3 \pm 20.8$ & $16.7 \pm 17.4$ \\
\hline
\end{tabular}

$\mathrm{QOL}=$ quality of life; $\mathrm{LCI} 3=$ lung-cancer-specific module. $* P<0.05$ compared with before therapy.

\section{Response to subsequent chemotherapy}

In total, 19 patients received second-line chemotherapy (CBDCA + TXL) subsequent to gefitinib. One had a CR, five had $\mathrm{PR}$, nine had SD, and four had PD. Overall response rate was $31.6 \%$ (6 out of 19); $95 \%$ CI was $10.7-52.5 \%$. The reasons of the 14 patients (one patients is still receiving gefitinib) who have not received the subsequent chemotherapy were patient's rejection to chemotherapy treatment $(n=8)$, patient's request for other regimens $(n=3)$ and worsening of general condition $(n=3)$.

\section{DISCUSSION}

Lung cancer is a major cause of cancer death in many countries in the world (Greenlee et al, 2000). Despite advances in treatment, a large meta-analysis of randomised trials demonstrated insufficient outcome of a 1-year survival benefit of $10 \%$ and a modest improvement in the median survival of 1.5 months for patients who were treated with platinum-containing regimens, compared with best supportive care (Non-small Cell Lung Cancer Collaborative Group, 1995). In addition, severe toxicities associated with platinum-based chemotherapy often led to treatment discontinuation. Therefore new drugs with novel modes of action that are effective and have less toxicities are needed. Gefitinib is a targeted drug with single-agent activity, and has shown mild toxicity in platina pretreated patients with NSCLC (Fukuoka et al, 2003; Kris et al, 2003).

As first-line therapy, gefitinib has been assessed in combination with two different chemotherapy regimens in two large randomised studies (IRESSA NSCLC Trial Assessing Combination Treatment (INTACT) 1 and INTACT 2) (Giaccone et al, 2004; Herbst et al, 2004). Disappointingly, both studies failed to show an improvement in either survival or other clinical end points.

A large placebo-controlled phase III study in patients with advanced NSCLC who had received one or two prior chemotherapy regimens, IRESSA Survival Evaluation in Lung Cancer (ISEL), showed some improvement in overall survival with single-agent gefitinib that failed to reach statistical significance compared with placebo in the overall or adenocarcinoma co-primary populations. However, there was marked heterogeneity in survival outcomes between patient groups, with some evidence of benefit among never-smokers and patients of Asian origin (Thatcher et al, 2005).

Little information is available for single-agent gefitinib as firstline therapy, and the available data are from compassionate use of gefitinib with a small number of patients (Argiris and Mittal, 2004; Niho et al, 2004).

In the present study, the overall response rate was $26.5 \%$. We demonstrated that gefitinib was active in patients with NSCLC as first-line single-agent therapy. It has been reported that gefitinib is more effective in women, in nonsmokers, in patients affected with adenocarcinoma and in patients of East Asian ethnicity (Fukuoka et al, 2003; Kris et al, 2003; Miller et al, 2004; Ho et al, 2005). As all of our patients were Japanese, it is not surprising that this response rate is higher than would be expected in other ethnicities (Argiris and Mittal, 2004; Kommareddy et al, 2004). In our subset analysis, women had a higher response rate than men (53.8 vs 9.5\%). However, other predicting factors such as smoking history or histology did not show any significant differences, possibly due to the small sample size.

Mutations in the TK domain of the EGFR have been identified in some patients with refractory NSCLC who achieved good responses to gefitinib (Cappuzzo et al, 2004; Lynch et al, 2004; Pao et al, 2004). Further recent studies suggest that the mutation status of EGFR-TK may predict clinical benefits with gefitinib (Marchetti et al, 2005; Mitsudomi et al, 2005; Yang et al, 2005). Different efficacy in different ethnicities may be explained by the different frequency of these mutations in different ethnic groups. 
Quality of life and toxicity are major considerations in the therapy of advanced lung cancer. It was reported that an improvement in QOL was observed in a gefitinib compassionateuse programme (Mu et al, 2004). In the present study, global health status did not change during gefitinib therapy. At 12 weeks of gefitinib therapy, improvement of insomnia and constipation, but worsening of appetite loss, diarrhoea, financial difficulties and alopecia were observed. Treatment with single-agent gefitinib therapy did not result in worsening of symptoms such as fatigue, nausea and vomiting.

Recently, concerns have arisen about an infrequent but serious side effect of gefitinib - interstitial pneumonia. A large randomised phase II study (IDEAL 1; Fukuoka et al, 2003) reported only two interstitial pneumonia cases out of 210 patients owing to gefitinib, and these cases were at a 500-mg dose of gefitinib. However, a surprisingly high incident rate of interstitial pneumonia (four of 18 patients) was reported from Japan (Inoue et al, 2003). Indeed, in a phase II study from Japan, four patients out of 42 patients developed grade 5 interstitial pneumonia (Niho et al, 2004). The incidence of pulmonary toxicity is thought to be higher in Japanese than in other ethnicities (FDA, 2003). Furthermore, it has been reported that the incidence of interstitial lung disease (ILD) in the Japanese patients on gefitinib was $4.5 \%$, and it was higher in the patients with pre-existing pulmonary fibrosis (Hotta et al, 2005). Furthermore, many chemotherapeutic agents have ILD information and precautions documented within their Japanese prescribing information. Reasons for the difference in reporting rate between Japan and the rest of world are unknown and require further scientific investigation. In the present study, we strictly excluded patients who had pulmonary fibrosis by chest CT, and no pulmonary toxicity occurred. Thus, in East Asia, patients should be very carefully selected and observed during gefitinib therapy.

In our study, the median survival time was 14.1 months, and the 1 -year survival rate was $58.2 \%$. Common toxicities were skin rash, general fatigue and liver dysfunction. However, there was no significant haematological or pulmonary toxicity. Gefitinib showed antitumour activity, even in stage IV NSCLC, with a good survival outcome.

In conclusion, phase III studies are warranted to compare platinum-containing regimens $v s$ gefitinib alone in the East Asian population.

\section{REFERENCES}

Aaronson NK, Ahmedzai S, Bergman B, Bullinger M, Cull A, Duez NJ, Filiberti A, Flechtner H, Fleishman SB, de Haes JC, Kaasa S, Klee M, Osoba D, Razavi D, Rofe PB, Schraub S, Sneeuw K, Sullivan M, Takeda F, for the European Organization for Research and Treatment of Cancer Study Group on Quality of Life (1993) The European Organization for Research and Treatment of Cancer QLQ-C30: a quality-of-life instrument for use in international clinical trials in oncology. J Natl Cancer Inst 85: $365-376$

Argiris A, Mittal N (2004) Gefitinib as first-line, compassionate use therapy in patients with advanced non-small-cell lung cancer. Lung Cancer 43: $317-322$

Cappuzzo F, Magrini E, Ceresoli GL, Bartolini S, Rossi E, Ludovini V, Gregorc V, Ligorio C, Cancellieri A, Damiani S, Spreafico A, Paties CT, Lombardo L, Calandri C, Bellezza G, Tonato M, Crino L (2004) Akt phosphorylation and gefitinib efficacy in patients with advanced nonsmall-cell lung cancer. J Natl Cancer Inst 96: 1133-1141

FDA (2003) FDA approves new type of drug for lung cancer. Web address available at: http://www.fda.gov/bbs/topics/NEWS/2003/NEW00901.html

Fukuoka M, Yano S, Giaccone G, Tamura T, Nakagawa K, Douillard JY, Nishiwaki Y, Vansteenkiste J, Kudoh S, Rischin D, Eek R, Horai T, Noda K, Takata I, Smit E, Averbuch S, Macleod A, Feyereislova A, Dong RP, Baselga J (2003) Multi-institutional randomized phase II trial of gefitinib for previously treated patients with advanced non-small-cell lung cancer. J Clin Oncol 21: 2237-2246

Giaccone G, Herbst RS, Manegold C, Scagliotti G, Rosell R, Miller V, Natale RB, Schiller JH, Von Pawel J, Pluzanska A, Gatzemeier U, Grous J, Ochs JS, Averbuch SD, Wolf MK, Rennie P, Fandi A, Johnson DH (2004) Gefitinib in combination with gemcitabine and cisplatin in advanced non-small-cell lung cancer: a phase III trial - INTACT 1. J Clin Oncol 22: $777-784$

Greenlee RT, Murray T, Bolden S, Wingo PA (2000) Cancer statistics, 2000. CA Cancer J Clin 50: 7-33

Herbst RS, Giaccone G, Schiller JH, Natale RB, Miller V, Manegold C, Scagliotti G, Rosell R, Oliff I, Reeves JA, Wolf MK, Krebs AD, Averbuch SD, Ochs JS, Grous J, Fandi A, Johnson DH (2004) Gefitinib in combination with paclitaxel and carboplatin in advanced non-small-cell lung cancer: a phase III trial - INTACT 2. J Clin Oncol 22: $785-794$

Ho C, Murray N, Laskin J, Melosky B, Anderson H, Bebb G (2005) Asian ethnicity and adenocarcinoma histology continues to predict response to gefitinib in patients treated for advanced non-small cell carcinoma of the lung in North America. Lung Cancer 49: 225-231

Hotta K, Kiura K, Tabata M, Harita S, Gemba K, Yonei T, Bessho A, Maeda T, Moritaka T, Shibayama T, Matsuo K, Kato K, Kanehiro A, Tanimoto Y, Matsuo K, Ueoka H, Tanimoto M (2005) Interstitial lung disease in Japanese patients with non-small cell lung cancer receiving gefitinib: an

analysis of risk factors and treatment outcomes in Okayama Lung Cancer Study Group. Cancer J 11: 417-424

Inoue A, Saijo Y, Maemondo M, Gomi K, Tokue Y, Kimura Y, Ebina M, Kikuchi T, Moriya T, Nukiwa T (2003) Severe acute interstitial pneumonia and gefitinib. Lancet 361: 137-139

Kommareddy A, Coplin MA, Gao F, Behnken D, Romvari E, Read W, Govindan R (2004) Single agent gefitinib as first line therapy in patients with advanced non-small cell lung cancer: Washington University experience. Lung Cancer 45: 221-225

Kris MG, Natale RB, Herbst R S, Lynch Jr TJ, Prager D, Belani CP, Schiller $\mathrm{JH}$, Kelly K, Spiridonidis H, Sandler A, Albain KS, Cella D, Wolf MK, Averbuch SD, Ochs JJ, Kay AC (2003) Efficacy of gefitinib, an inhibitor of the epidermal growth factor receptor tyrosine kinase, in symptomatic patients with non-small cell lung cancer: a randomized trial. JAMA 290: $2149-2158$

Lynch TJ, Bell DW, Sordella R, Gurubhagavatula S, Okimoto RA, Brannigan BW, Harris PL, Haserlat SM, Supko JG, Haluska FG, Louis DN, Christiani DC, Settleman J, Haber DA (2004) Activating mutations in the epidermal growth factor receptor underlying responsiveness of non-small-cell lung cancer to gefitinib. N Engl J Med 350: 2129-2139

Marchetti A, Martella C, Felicioni L, Barassi F, Salvatore S, Chella A, Camplese PP, Iarussi T, Mucilli F, Mezzetti A, Cuccurullo F, Sacco R, Buttitta F (2005) EGFR mutations in non-small-cell lung cancer: analysis of a large series of cases and development of a rapid and sensitive method for diagnostic screening with potential implications on pharmacologic treatment. J Clin Oncol 23: $857-865$

Miller VA, Kris MG, Shah N, Patel J, Azzoli C, Gomez J, Krug LM, Pao W, Rizvi N, Pizzo B, Tyson L, Venkatraman E, Ben-Porat L, Memoli N, Zakowski M, Rusch V, Heelan RT (2004) Bronchioloalveolar pathologic subtype and smoking history predict sensitivity to gefitinib in advanced non-small-cell lung cancer. J Clin Oncol 22: 1103-1109

Mitsudomi T, Kosaka T, Endoh H, Horio Y, Hida T, Mori S, Hatooka S, Shinoda M, Takahashi T, Yatabe Y (2005) Mutations of the epidermal growth factor receptor gene predict prolonged survival after gefitinib treatment in patients with non-small-cell lung cancer with postoperative recurrence. J Clin Oncol 23: 2513-2520

Mu, XL, Li LY, Zhang XT, Wang SL, Wang MZ (2004) Evaluation of safety and efficacy of gefitinib ('iressa', zd1839) as monotherapy in a series of Chinese patients with advanced non-small-cell lung cancer: experience from a compassionate-use programme. BMC Cancer 4: 51

Niho S, Kubota K, Goto K, Yoh K, Ohmatsu H, Kakinuma R, Saijo N, Nishiwaki Y (2004) First-line single agent of gefitinib in patients(pts) with advanced non-small cell lung cancer (NSCLC): a phase II study. J Clin Oncol 22: 14S: 631s 
Non-small Cell Lung Cancer Collaborative Group (1995) Chemotherapy in non-small cell lung cancer: a meta-analysis using updated data on individual patients from 52 randomised clinical trials. BMJ 311: 899-909

Pao W, Miller V, Zakowski M, Doherty J, Politi K, Sarkaria I, Singh B, Heelan R, Rusch V, Fulton L, Mardis E, Kupfer D, Wilson R, Kris M, Varmus H (2004) EGF receptor gene mutations are common in lung cancers from 'never smokers' and are associated with sensitivity of tumors to gefitinib and erlotinib. Proc Natl Acad Sci USA 101: 1330613311

Ranson M, Hammond LA, Ferry D, Kris M, Tullo A, Murray PI, Miller V, Averbuch S, Ochs J, Morris C, Feyereislova A, Swaisland H, Rowinsky EK (2002) ZD1839, a selective oral epidermal growth factor receptortyrosine kinase inhibitor, is well tolerated and active in patients with solid, malignant tumors: results of a phase I trial. J Clin Oncol 20: $2240-2250$

Schiller JH, Harrington D, Belani CP, Langer C, Sandler A, Krook J, Zhu J, Johnson DH, Eastern Cooperative Oncology Group (2002) Comparison of four chemotherapy regimens for advanced non-small-cell lung cancer. $N$ Engl J Med 346: $92-98$

Thatcher N, Chang A, Parikh P, Pereira JR, Ciuleanu T, von Pawel J, Thongprasert S, Tan E-H, Pemberton K, Archer V, Carroll K (2005) Gefitinib plus best supportive care in previously treated patients with refractory advanced non-small-cell lung cancer: results from a randomised, placebo-controlled, multicentre study (IRESSA Survival Evaluation in Lung Cancer). Lancet 366: 1527-1537

Wakeling AE, Barker AJ, Davies DH, Brown DS, Green LR, Cartlidge SA, Woodburn JR (1996) Specific inhibition of epidermal growth factor receptor tyrosine kinase by 4 -anilinoquinazolines. Breast Cancer Res Treat 38: $67-73$

Yang SH, Mechanic LE, Yang P, Landi MT, Bowman ED, Wampfler J, Meerzaman D, Hong KM, Mann F, Dracheva T, Fukuoka J, Travis W, Caporaso NE, Harris CC, Jen J (2005) Mutations in the tyrosine kinase domain of the epidermal growth factor receptor in non-small cell lung cancer. Clin Cancer Res 11: 2106-2110 